\title{
$\mathrm{B} / u$ TIJDSCHRIFTEN
}

\section{Observeren in de rechtszaal}

\section{Nienke Doornbos}

Aanbevolen citeerwijze bij dit artikel

Nienke Doornbos, 'Observeren in de rechtszaal', ReM 2014-03, p.

\begin{abstract}
'Ik had verwacht dat de deelnemers van een rechtszitting formeel met elkaar zouden communiceren. Maar dat was niet het geval. Ik heb nog dat ouderwetse beeld waarbij er eindeloos respect is voor hoge functies zoals een rechter en een advocaat. Deze posities werden gezien als "ongrijpbaar" voor de gewone man, wat het autoritaire aspect versterkte. Mijn opa is bijvoorbeeld zijn hele leven boer geweest. Hij is nu begin negentig en hij vindt het ongelofelijk dat ik advocaat wil worden. Hij is ontzettend trots. (...) Bij mij heerste ook het beeld dat de rechters en advocaten op hoog niveau met elkaar delibereerden, waarbij de cliënten er zwijgend bij zouden zitten. Maar niets is minder waar, alle partijen praten door elkaar heen, onverhoopt worden de rechters getutoyeerd en advocaten worden uitgescholden voor leugenaar. Ik wijt het aan de informalisering van de maatschappij die begin jaren zeventig doorbrak.' (Fragment uit een observatieverslag van een derdejaars bachelorstudente Rechtsgeleerdheid)
\end{abstract}

Voor studenten is het bezoek aan een rechtbank en het observeren van een rechtszitting vrijwel altijd een eyeopener. Het beeld dat zij van de rechtspraak hebben - tot dan toe voornamelijk gevormd door berichtgeving in de media en door studie - moet na zo'n ervaring meestal bijgesteld worden. Een doorsnee rechtszaak heeft bijvoorbeeld helemaal niet zo'n hoog juridisch gehalte. Voor eenvoudige strafzaken of vreemdelingenzaken wordt maar korte tijd (10 tot 15 minuten) uitgetrokken. Rechters blijken niet louter autoriteit uit te stralen, maar stellen zich ook empathisch op. Het juridisch jargon dat ter zitting wordt gebruikt, is vooral voor rechtzoekenden die slecht Nederlands verstaan en spreken een probleem, temeer omdat sommige tolken niet alles vertalen. En met de privacy van gedaagden bij de rolzitting van de kantonrechter is het slecht gesteld. Tot dit soort reflectieve gedachten komen studenten na een bezoek aan de rechtszaal. De observatie dwingt hen ertoe het rechtsbedrijf van een afstandje te bekijken en brengt hen tot nieuwe opvattingen. Zowel het routinematige karakter als de menselijke aspecten van rechtspraak springen daarbij in het oog.

Hoewel vrijwel alle rechtenstudenten vroeg of laat in hun studie de opdracht krijgen om eens een kijkje te nemen bij de rechtbank, is er niet of nauwelijks literatuur over hoe ze dat zouden kunnen aanpakken. Literatuur over de resultaten van observatieonderzoek in de rechtszaal ${ }^{1}$ is er genoeg, maar over de 
methodologie van een dergelijke observatieopdracht is naar mijn weten geen handzaam artikel beschikbaar. ${ }^{\mathbf{2}}$ Dit artikel beoogt in die leemte te voorzien. Het doel is om studenten methodologische bagage mee te geven, waarmee een observatieopdracht op een hoger niveau kan worden getild. Promovendi of andere onderzoekers die observatieonderzoek willen verrichten, kunnen daar ook hun voordeel mee doen. Hen zou ik ook zou willen verwijzen naar methodologische handboeken en meer specialistische literatuur. ${ }^{3}$ Ook rechters in opleiding kunnen deze kennis gebruiken. Dit artikel is echter in eerste instantie bedoeld voor gebruik in het hoger onderwijs en richt zich rechtstreeks tot de rechtenstudent. Aan de orde komen (1) het doel van de observatie, (2) de kracht en beperkingen van deze methode, (3) de vraagstelling, (4) de rol van de onderzoeker, (5) de voorbereiding, (6) de uitvoering van de observatie en (7) de verslaglegging. Ter illustratie put ik op verschillende plaatsen in dit artikel uit de verslagen die studenten van de Universiteit van Amsterdam in het kader van de minor Rechtswetenschappelijk onderzoek de afgelopen jaren hebben gemaakt.

\section{Het doel van de observatie}

Indien je wordt gevraagd te observeren in de rechtszaal kan dat verschillende doelen dienen. Een bezoek aan de rechtbank voor een positiefrechtelijk vak als Strafrecht of Personen- en Familierecht heeft voornamelijk ten doel om je kennis te laten maken met de inhoudelijke afweging van rechten en belangen. Het is de bedoeling dat je vertrouwd raakt met juridische afwegingen en ziet hoe bepaalde complexe leerstukken als 'voorwaardelijke opzet' of 'belang van het kind' in de praktijk worden toegepast. In het eventuele verslag van dit bezoek staan de juridische aspecten centraal: Tot welke uitspraak is de rechtbank gekomen? Passen de argumenten en oplossingen binnen het stelsel van wet en jurisprudentie? Sluit de uitspraak aan bij de rechtsontwikkeling?

Het kan ook zijn dat je in het kader van een metajuridisch vak als Rechtssociologie, Rechtspraktijk of in een ander empirisch vak de opdracht krijgt om een rechtszitting te observeren. In dat geval is het primaire doel doorgaans om de law in the books te vergelijken met de law in action. Bovendien doe je ervaring op met de methode van observeren. Als rechtenstudent word je daar, anders dan studenten in de sociale wetenschappen, doorgaans niet in getraind. Dit artikel voorziet hierin door enkele basale begrippen vanuit de sociaalwetenschappelijke methodologische literatuur toe te passen op de context van de rechtszaal.

In beide gevallen heeft de observatie een functie in het socialisatieproces van jou als rechtenstudent. Socialisatie is wel omschreven als een levenslang proces waarbij iemand, bewust en onbewust, de regels, verwachtingen, kennis en vaardigheden leert, die nodig zijn om in een bepaalde samenleving bepaalde rollen te vervullen. ${ }^{4}$ Als student (jurist in spe) ben je nog geen deelnemer, maar word je wel alvast ingewijd in de gebruiken en rituelen van de rechtspraktijk. De juridische procesdeelnemers - de rechter, de advocaat, de officier van justitie en andere procesvertegenwoordigers - fungeren daarbij als rolmodel. Het leuke van een observatieopdracht is dat je het tafereel van een rechtszitting (vaak wordt de metafoor van het theater gebruikt ${ }^{5}$ ) van buitenaf waarneemt. Dat biedt je de mogelijkheid om deze setting eens kritisch te bekijken: Welke dilemma's roept deze setting op? Vind je de procedure en de interactie tussen de procesdeelnemers goed verlopen of niet? Waarom? Is dit een setting waarbinnen jij zelf graag zou willen werken? 


\section{De kracht en de beperkingen van de methode}

De kracht van de methode van observatie is dat het de interacties tussen de procesdeelnemers en procespartijen levendig in beeld kan brengen. Er wordt inzicht verkregen in de wijze waarop procedures in de praktijk worden doorlopen en in de interactieprocessen waarbinnen het recht daadwerkelijk wordt vormgegeven. Zo krijgt het recht pas werkelijk reliëf. Observatieonderzoek vindt doorgaans plaats binnen de etnografische onderzoekstraditie. Etnografie is een verzameling van interpretatieve benaderingen binnen de sociologie ${ }^{\mathbf{6}}$, die zich bezighouden met de sociale organisatie van alledaagse activiteiten binnen de samenleving. De interactie wordt daarbij opgevat als een sociale constructie: een werkelijkheid die wordt geschapen doordat de participanten in een subtiel proces betekenis verlenen aan de uitlatingen van de ander. ${ }^{7}$

Observatieonderzoek kan veel zeggingskracht en diepgang hebben, maar kent ook beperkingen. Als je observeert, neem je gedrag waar en dus geen meningen of gedachten die zich louter in de hoofden van degenen die je observeert afspelen. Zolang een rechter niet schriftelijk of mondeling motiveert waarom hij een bepaalde uitspraak doet, kom je over die achterliggende redenen niets te weten als je je beperkt tot observaties (in veel etnografisch onderzoek worden observaties daarom aangevuld met interviews). Soms kun je uit gedrag, bijvoorbeeld uit de non-verbale signalen die iemand afgeeft, wel enigszins afleiden hoe iemand zich voelt of wat iemand denkt, maar dit kan al snel leiden tot subjectieve waarnemingen. Subjectiviteit wil zeggen dat verschillende mensen de dingen die ze waarnemen verschillend kunnen waarderen en interpreteren. In observatieonderzoek wil de onderzoeker juist het tegenovergestelde bewerkstellingen, namelijk objectiviteit: er is sprake van eenduidige waarnemingen, waarbij de persoon van de onderzoeker geen enkele rol speelt. Hoewel dit een nastrevenswaardig doel is, zal het nooit volledig kunnen worden bereikt, net zomin overigens als bij andere onderzoeksmethoden. ${ }^{\mathbf{8}}$ Als onderzoeker kun je je interesses, voorkeuren, opvattingen, voorkennis, aannames en vooroordelen immers niet zo maar uitschakelen, ook al omdat je je er niet volledig van bewust bent. Je waarneming wordt bovendien altijd beïnvloed door theorieën en verwachtingen, al is het maar een common sense verwachting, zoals van de hierboven geciteerde studente, dat de omgangsvormen binnen de rechtbank formeel van aard zouden zijn.

Bij observatie ben je afhankelijk van je zintuiglijke waarneming en die is per definitie beperkt. Je kunt niet alles tegelijkertijd waarnemen. Vanuit de publieke tribune in de rechtszaal heb je bij strafzaken bijvoorbeeld wel goed zicht op de rechter, de griffier en de officier van justitie, maar zijn de verdachte en zijn advocaat veelal slechts op de rug te zien. De verstaanbaarheid in de rechtszaal laat ook nog wel eens te wensen over. ${ }^{9}$ De huisregels van de rechtbank laten het niet toe dat zonder toestemming geluid- of beeldopnames worden gemaakt. Maar zelfs als je wel alles zou kunnen horen of zien, dan nog ben je niet in staat om alle verbale en non-verbale uitingen waar te nemen en te registreren. Je waarneming is dus per definitie selectief.

Dit soort beperkingen zijn inherent aan de methode van observatie. Het komt erop aan die beperkingen niet te verdoezelen, maar om ze onder ogen te zien. Het doen van onderzoek draait voor een groot deel om het maken van de juiste keuzes en om het verantwoorden van die keuzes. Dat is bij observatieonderzoek 
niet anders dan bij andere onderzoeksmethoden. Wat goede keuzes zijn, hangt bij een eenmalig rechtbankbezoek in het kader van de studie vooral af van kwesties als uitvoerbaarheid en haalbaarheid. Als het gaat om een meeromvattend onderzoek of een promotieonderzoek, spelen uiteraard ook wetenschappelijke eisen zoals een systematische werkwijze, repliceerbaarheid, generaliseerbaarheid en vernieuwend karakter van het onderzoek een rol.

In schema 1 zijn de belangrijkste keuzes weergegeven die bij observatieonderzoek een rol spelen. Het gaat hier om uitersten op een glijdende schaal. Soms kan een combinatie van mogelijkheden worden gekozen, is het niet een kwestie van 'of-of', maar van 'en-en' of van 'meer of minder'.

Schema 1Keuzes bij het ontwerpen van een observatieonderzoek

\begin{tabular}{|l|l|l|}
\hline Grootschalig & $\rightarrow \leftarrow$ & Kleinschalig \\
\hline Kwantificeerbaar & $\rightarrow \leftarrow$ & Kwalitatief \\
\hline Gericht op verbale interactie & $\rightarrow \leftarrow$ & Gericht op non-verbale interactie \\
\hline Participeren & $\rightarrow \leftarrow$ & Niet participeren \\
\hline Open rol & $\rightarrow \leftarrow$ & Verborgen rol \\
\hline Gestructureerd & $\rightarrow \leftarrow$ & Ongestructureerd \\
\hline
\end{tabular}

Bron: Deels gebaseerd op Verhoeven 2011, p. 144.

De drie eerstgenoemde keuzes hebben consequenties voor de vraagstelling van het onderzoek en worden hieronder als eerste besproken. De kwesties participeren/niet participeren, open/verborgen hebben betrekking op de rol van de onderzoeker en komen daarna aan de orde. De keuze tussen vrije waarneming of (meer) gestructureerde waarneming betreft de uitvoering van de observatie en komt als laatste aan bod.

\section{De vraagstelling}

Uit een statistisch onderzoek gebaseerd op observaties uit de jaren tachtig bleek dat werklozen aanzienlijk zwaarder en langduriger gestraft werden dan werkenden. ${ }^{\mathbf{1 0}}$ In 2012 werden de resultaten bekend van een grootschalig observatieonderzoek, waaruit onder meer naar voren kwam dat daders met een buitenlands uiterlijk een veel grotere kans hebben om (langdurig) achter de tralies te verdwijnen dan autochtone daders, zeker als zij ook nog eens de Nederlandse taal niet machtig zijn. ${ }^{\mathbf{1 1}}$ Dit soort grootschalige observatieonderzoeken, gericht op het achterhalen van causale relaties via statische (kwantitatieve) methoden, is in Nederland tamelijk uitzonderlijk. Dergelijk onderzoek is zeer arbeidsintensief en dus kostbaar. De meeste onderzoeken zijn beperkter van opzet; dat geldt per definitie voor de observaties die studenten in het kader van een onderzoeksopdracht kunnen doen. De vraagstelling dient daarop afgestemd te worden.

Dat dit niet voor alle studenten evident is, blijkt wel uit het volgende. Een studente formuleerde de onderzoeksvraag: 'Komt de onafhankelijkheid van de rechter tot uiting in zijn gedragingen?’ Deze onderzoeksvraag diende zij verder te operationaliseren ('vertalen') naar een waarnemingsvraag. Operationalisatie 
wil zeggen: onderzoeksklaar maken van abstracte begrippen, in dit geval: concretiseren op welke gedragingen wordt gelet om vervolgens uitspraken te kunnen doen over het betreffende onderwerp (onafhankelijkheid van de rechter). De studente operationaliseerde de onderzoeksvraag in de waarnemingsvraag of rechters door lichaamstaal (namelijk door te knikken en op een bepaalde manier te schudden met hun hoofd) uitdrukking geven aan hun voorkeuren. De veronderstelling dat dit type lichaamstaal iets zegt over voorkeuren, had theoretisch onderbouwd kunnen worden ${ }^{\mathbf{1 2}}$, maar deze student kwam in dat opzicht helaas niet verder dan te verwijzen (zonder bronvermelding) naar een 'onderzoek' op internet.

Uit haar observatieverslag haal ik het volgende fragment:

\begin{abstract}
'De zitting kwam kort gezegd neer op een verleende bouwvergunning voor een grote aanbouw aan een huis, waar zeer veel buurtbewoners uit de straat het niet mee eens waren, dit omdat dit ten koste zou gaan van de leefbaarheid van de buurt. Hierbij heb je dus aan de ene kant een grote groep buurtbewoners met een gemachtigde zitten en aan de andere kan maar één gemachtigde namens de gemeente. Bij elkaar opgeteld heb ik de drie rechters 43 keer zien knikken naar de buurtbewoners en maar 8 keer zien schudden. In de richting van de gemachtigde van de gemeente heb ik de rechters 20 keer zien knikken en 6 keer zien schudden. De rechters bleven naar voren gericht zitten, ik kon niet duidelijk opmaken of dit meer gericht was naar één van de partijen. Maar uit het feit dat er in de richting van de buurtbewoners veel vaker werd geknikt dan in de richting van de gemachtigde van de gemeente, maak ik op dat de rechters het meer eens waren met de buurtbewoners'.
\end{abstract}

Aan het slot van het verslag verzucht deze student:

'Ik zou eigenlijk de uitspraken te zijner tijd moeten opzoeken om te controleren of mijn hypothese waarheid is geworden.'

De student legt de vinger op de zere plek. Dit type onderzoek kan interessant zijn als het grootschalig wordt uitgevoerd en als daarbij een statistische vergelijking wordt gemaakt met de uitkomsten van de zaken. Maar in een enkele waarneming is het knikken en schudden van hoofden van rechters niet zo veelzeggend. Wellicht speelden heel andere aspecten een rol in de redenen waarom rechters vaker knikten richting de buurtbewoners. Misschien knikten de rechters vaker omdat er zo'n groot gezelschap voor hen zat of omdat de bewoners langer aan het woord waren? We zullen het niet weten. Voor nu is van belang om te constateren dat observatieonderzoek in het kader van een studie per definitie kleinschalig onderzoek oplevert en dat daar bij het formuleren van de onderzoeksvraag maar beter rekening mee kan worden gehouden. Het voorbeeld laat tevens zien dat het vaak moeilijk is om conclusies te verbinden aan lichaamstaal, zonder daarbij de verbale interactie of de beslissing te betrekken.

Neem nu de tegenovergestelde situatie van een student die in een abstract begrip is geïnteresseerd en dit in woorden (in plaats van cijfers) probeert te duiden. Deze student richt zich dus niet op kwantificeerbare gegevens, maar heeft een meer interpretatieve aanpak. Deze student was tijdens een hoorcollege geïntrigeerd geraakt door een opmerking van een hoogleraar, tevens plaatsvervangend rechter, dat rechters in het strafproces een 'sacrale sfeer' 
creëren. Hoewel de student nog nooit zelf een rechtszaak had bijgewoond, had hij toch direct een idee wat daarmee bedoeld werd, zo schrijft hij in zijn observatieverslag. Iets van 'hier gebeurt iets belangrijks, daar doen we niet luchtig over'. Hij besluit:

'de observatieopdracht aan te wenden om nauwlettend te bekijken wat die sacrale sfeer nu is, hoe de verschillende deelnemers aan het strafproces ermee omgaan, en of er ook elementen zijn die er juist afbreuk aan doen.'

Met name over die laatste toevoeging waren de docenten zeer te spreken, omdat het expliciet zoeken naar tegenvoorbeelden bij uitstek een goede strategie is om te voorkomen dat je zozeer gefocust bent op het verschijnsel dat je wilt waarnemen dat je in alles een bevestiging van je hypothesen ziet en je niet meer in staat bent om verschijnselen in de juiste proporties te zien ('tunnelvisie' voor onderzoekers).

Bij de operationalisatie van dit abstracte begrip gaat de student niet over één nacht ijs. Nadat hij aan de hand van het Van Dale groot woordenboek van de Nederlandse taal heeft vastgesteld dat vooral de betekenis van sacraal als heilig, geheiligd of gewijd van toepassing is, zoekt hij aansluiting bij de etymologie van het woord sacraal en komt tot de bevinding dat
'een sacrum in het Latijn naast de overduidelijke religieuze grondbetekenis ook andere in het oog springende eigenschappen heeft: het gaat om dingen die los staan van het dagelijks leven, die omgeven zijn met rituelen en die iets geheimzinnigs hebben maar ook, of misschien wel daardoor, onaantastbaar zijn'. ${ }^{13}$

Vervolgens gaat hij van elk deze elementen na wat hij ervan merkt in de manier waarop hij toegang krijgt tot de zitting; de aankleding en inrichting van de zaal waar de zitting plaatsvindt; de kleding en uiterlijke verzorging van de deelnemers aan het proces; het gedrag en de lichaamshouding van de deelnemers; en tot slot het woordgebruik van de deelnemers. Een fragment uit zijn bevindingen:
'Dat de vier zich terugtrokken in een apart vertrek om daar te beraadslagen had duidelijk iets geheimzinnigs. Bovendien verleende het de beslissing ook meer gezag, denk ik, dan wanneer ze en plein publique hadden overlegd en het misschien niet met elkaar eens waren geweest. Nu sprak er eenheid uit de beslissing en kreeg je de indruk dat allen er achter stonden. (...) Nog meer blijk van gezag was het feit dat de aanklager en de rechters op een hoger niveau zaten dan de beklaagde en de verdediger. Ook de terminologie die de verdediger [advocaat, ND] bezigde tegenover de voorzitter zoals 'geacht college' en het opstaan bij binnenkomst en weggaan van de vier waren gedragingen die op mij overkwamen als om het gezag van de rechters te appreciëren, en daarmee alles wat er in het zaaltje gebeurde onder leiding van de voorzitter.'

De student concludeert dat in de geobserveerde zaak 'het sacrale de boventoon voerde maar dat er ook ruimte was voor menselijkheid'.

Beide voorbeelden overziend wordt het duidelijk dat de vraagstelling en de operationalisatie daarvan cruciaal zijn en tot wezenlijk verschillende 
onderzoeksstrategieën en observatieverslagen kunnen leiden. Uiteraard zijn er mengvormen mogelijk, waarbij op zowel formele (meetbare) als inhoudelijke (kwalitatieve) aspecten wordt gelet.

Zo heeft Peter Bal (1988) bijvoorbeeld een mooi observatieonderzoek verricht naar de ongelijke machtsconstellatie binnen de rechtbank en de gevolgen daarvan voor de communicatie ter zitting. Daarbij lette hij op een aantal formele kenmerken van de communicatie (bijv. het aantal spreekbeurten en de spreekduur van de verschillende participanten), maar bovenal ging hij in op de wijze waarop vragen worden gesteld (bijv. meer open of meer gesloten) en de gradaties van dwang die uitgaan van ondervragingstechnieken. Bal spreekt in zijn studie van 'strategische interactie' tussen rechter en verdachte. Strategische interactie is niet in de eerste plaats gericht op het bereiken van intersubjectief gedeeld begrip tussen de deelnemers, maar op het bereiken van officiële en officieuze doelen, die zijn terug te voeren op de eigen, vaak tegengestelde belangen van de deelnemers. Volgens Bal is in de rechtszaal sprake van 'dwangkommunikatie': een gesprek of gesprekssituatie waarin een meer machtige deelnemer een minder machtige met verbale middelen noodzaakt op een door de eerste bepaalde wijze aan het gesprek deel te nemen. Hij dwingt met andere woorden de ander tot spreken of tot zwijgen. Hierdoor kan hij het gespreksverloop en de uitkomst beheersen en sturen. De minder machtige gespreksdeelnemer kan zich hiertegen niet of nauwelijks teweerstellen. Hij wordt aan dwangcommunicatie onderworpen en kan zich daaraan niet onttrekken zonder dat dit nadelige gevolgen voor hem heeft. ${ }^{\mathbf{1 4}}$

Het onderzoek van Bal heeft vele aspecten van de verbale interactie ter terechtzitting op een mooie manier aan het licht gebracht, maar aan de keuze voor de thematiek, de terminologie en zelfs de spelling waarin deze is gevat ('dwangkommunikatie') kun je goed aflezen dat observaties ook iets zeggen over de persoon van de onderzoeker en altijd tot op zekere hoogte tijd- en plaatsgebonden zijn. Onderzoekers zijn in zekere zin altijd een product van de tijd waarin zij leven en het land waarbinnen zij zijn opgegroeid ('gesocialiseerd'). ${ }^{\mathbf{1 5}}$ Dit brengt ons op het volgende onderwerp.

\section{De rol van de onderzoeker}

Tot nog toe zijn we er stilzwijgend van uitgegaan dat de studentonderzoeker plaatsneemt op de publieke tribune en min of meer als buitenstaander het proces gadeslaat. In sociaalwetenschappelijke termen spreken we van nietparticiperende observatie (participerende observatie houdt in dat de onderzoeker zelf deelneemt aan de praktijk die hij onderzoekt).

In het debat over participerende en niet-participerende observatie doet zich een interessante tegenstelling voor tussen juristen en sociaal wetenschappers. Juristen hebben namelijk vaak het idee dat je de rechtspraktijk pas echt goed kunt leren kennen als je er deel van uitmaakt. De toepassing van het recht en het proces van rechterlijke besluitvorming vereist zoveel specifieke kennis en vaardigheden dat alleen ingewijden daar goed inzicht in hebben. Zo krijgt een promovenda die aan de Universiteit van Amsterdam onderzoek doet naar de rol van juridisch medewerkers in rechterlijke besluitvorming regelmatig het advies om zelf enige tijd als gerechtssecretaris te gaan werken. Een promovendus die aan de Radboud Universiteit onderzoek doet naar de meerwaarde van meervoudige rechtspraak versus enkelvoudige rechtspraak heeft dat ook daadwerkelijk gedaan. Beiden hebben toegang gekregen tot het 
raadkameroverleg, wat wel wordt gezien als het 'walhalla' voor onderzoekers naar rechterlijke besluitvorming. ${ }^{\mathbf{1 6}}$

In de sociaalwetenschappelijke literatuur tref je drie typen argumenten aan die ertegen pleiten om al te vergaand te participeren in de situaties die je wilt observeren. Het eerste argument houdt in dat als je zelf deel uitmaakt van de rechtspraktijk, zeker als je (mede)verantwoordelijk bent voor rechterlijke oordelen of de verslaglegging daarvan, je niet meer in staat bent om met de vereiste distantie naar je onderzoeksobject te kijken. In plaats van je kritisch af te vragen waarom mensen handelen zoals ze handelen, ben je in zo'n geval sneller geneigd om het gedrag te gaan verantwoorden of mooier voor te stellen dan het is. Dat is uiteraard niet jouw taak als onderzoeker.

Terzijde: in de culturele antropologie, waar bij uitstek participerend wordt geobserveerd, wordt in zo'n geval wel gesproken van going native: de situatie waarin een onderzoeker er niet alleen voor kiest om enige tijd bij een te bestuderen bevolkingsgroep te gaan wonen, maar zich daar zozeer in onderdompelt dat hij zich gaat vereenzelvigen met zijn onderzoekssubjecten, zijn rol als onderzoeker uit het oog verliest en er wellicht uiteindelijk zelfs voor kiest om in hun traditie verder te leven. ${ }^{\mathbf{1 7}}$ Ook bij biologen komt dit in een uiterst geval voor, denk maar aan Jane Goodall (biologe gespecialiseerd in gorilla's) of aan Timothy Treadwell (natuurbeschermer, gespecialiseerd in grizzlyberen), over wie de documentaire Grizzly Man is gemaakt. Zo slecht als het met de 'grizzly man' afliep, zal het een onderzoeker binnen de rechtspraktijk niet snel overkomen, maar het kritisch beschrijven van een praktijk waar je zelf deel van uitmaakt of zelf verantwoordelijkheid voor draagt is heel moeilijk en zal je vaak ook niet in dank worden afgenomen door je respondenten. ${ }^{\mathbf{1 8}}$

Een tweede reden om niet al te vergaand te participeren is dat je daarmee de praktijken die je observeert kunt beïnvloeden. Door mee te doen gaan dingen wellicht anders dan anders. Als de hierboven genoemde promovendi bijvoorbeeld in raadkamer mee zouden discussiëren over de zaken die tegelijkertijd onderwerp van hun onderzoek zijn, zouden zij interfereren in hun onderzoek en daarmee hun eigen onderzoeksresultaten beïnvloeden.

Een derde argument tegen een te vergaande participatie in eigen onderzoek, tot slot, is praktisch van aard. Juristen onderschatten vaak het werk dat onderzoek doen met zich brengt. Het voorbereiden van observatieonderzoek, het bijwonen van zittingen en het verslag doen daarvan is op zichzelf al een dagtaak. Omgekeerd is een baan als griffier ook een volwaardige inspanning. Zo moet van de zitting vaak ter plekke op de computer een proces-verbaal worden gemaakt dat focust op de inhoud van wat er gezegd is. Voor observaties over de gang van zaken of het gedrag van de deelnemers kan men dan veel minder oog hebben.

Hiermee is natuurlijk niet gezegd dat juristen geen goede observaties kunnen maken, laat staan dat alleen sociaal wetenschappers hiertoe in staat zouden zijn. Integendeel. Er zijn voorbeelden van rechters die juist zeer rake observaties kunnen maken van hun eigen werkzaamheden of die van collega's. ${ }^{\mathbf{1 9}}$

In de praktijk wordt bij onderzoek vaak voor een tussenvorm gekozen, waarbij de onderzoeker bijvoorbeeld enige maanden in de rechtbank verblijft en probeert zo veel mogelijk situaties te observeren, zonder zelf verantwoordelijkheden te dragen die betrekking hebben op het te observeren 
gedrag. ${ }^{20}$ Ook dan spreekt men overigens nog van participerende observatie: de onderzoeker neemt wel deel aan alle activiteiten, maar heeft geen of slechts een zeer beperkte inhoudelijke inbreng.

\subsection{Verborgen of open rol?}

Vrijwel alle rechtspraak in Nederland is openbaar. Er is doorgaans geen toestemming vereist om een rechtszitting bij te wonen. Sommige rechtszaken hebben echter zo'n privaat karakter dat het wel opvalt en vragen oproept als daar een bezoeker bij aanwezig is, zeker als deze ter plekke aantekeningen maakt (denk bijvoorbeeld aan een echtscheidingszaak). In zo'n geval is het netter om vooraf even kennis te maken met de procespartijen en in globale bewoordingen het doel van het bezoek toe te lichten. De bode kan hierbij behulpzaam zijn. Indien mensen bezwaar hebben tegen bijwoning van de zitting vanwege het privékarakter daarvan of om andere redenen, zou je weliswaar kunnen wijzen op de openbaarheid van rechtspraak, maar hier is nog iets anders in het geding, namelijk de wens van mensen om niet tegen hun zin in betrokken te worden bij onderzoek. Dat is een legitieme wens die gerespecteerd dient te worden. In gedragscodes voor onderzoekers wordt dit ook erkend. Zo schrijft artikel I.2 van de gedragscode van de Vereniging van Universiteiten VSNU 2012 voor:

\footnotetext{
'ledere wetenschapsbeoefenaar toont respect voor mensen en dieren die betrokken zijn bij wetenschappelijk onderwijs en onderzoek. Onderzoek met mensen is principieel slechts mogelijk als zij "informed consent" hebben verleend en de risico's gering zijn. De privacy van de betrokkenen wordt afdoende beschermd. Als onderzoek met mensen of dieren enig risico oplevert, moet het belang van het onderzoek het nemen van dat risico rechtvaardigen.'
}

Ook rechters plegen nogal eens te informeren bij bezoekers wie zij zijn en met welk doel zij de zitting bijwonen. Als onderzoeker moet je hierop voorbereid zijn. Het volstaat om in globale bewoordingen aan te duiden dat je de rechtbank bezoekt vanwege studie of onderzoek. Als een rechter doorvraagt naar de aard van het onderzoek, kun je dat in algemene termen aangeven (je bent bijvoorbeeld 'geïnteresseerd in de gang van zaken bij arbeidszaken'). Probeer in elk geval te vermijden dat je ongevraagd prijs geeft op welk type gedragingen je precies let. ${ }^{\mathbf{2 1}}$ Dat leidt namelijk tot wat in de sociale wetenschappen wordt genoemd reactief gedrag bij de onderzoekssubjecten. De deelnemers aan de rechtszitting kunnen dan geneigd zijn zich anders te gaan gedragen, meer 'volgens het boekje', op het moment dat zij weten dat jij in een bepaald aspect bent geïnteresseerd, bijvoorbeeld of rechters zich ter zitting meer lijdelijk, dan wel meer actief gedragen. Anders dan voor procespartijen is het voor de professionele procesdeelnemers niet legitiem om zich te beroepen op hun recht op privacy; er is naar mijn mening geen goede reden denkbaar waarom de openbaarheid van rechtspraak bij hen (professionals) niet zou prevaleren boven hun recht op privacy. Het beginsel van externe openbaarheid heeft immers als achtergrond dat externe controle op rechtspraak mogelijk moet zijn.

\section{De voorbereiding}

Er zijn onderzoekers, zoals Bruno Latour, die claimen dat observaties aan kracht winnen door volledig 'blanco' (zonder enige voorkennis) het 'veld' in te gaan. ${ }^{\mathbf{2 2}}$ Daar valt iets voor te zeggen, maar een rechtenstudent heeft nu eenmaal al 
zoveel voorkennis en verwachtingen dat dit niet meer mogelijk is. Enige voorbereiding kan bovendien goed van pas komen. Neem om te beginnen een virtueel kijkje in de rechtszaal $^{\mathbf{2 3}}$, kijk wie de hoofdrolspelers zijn en wat hun vaste plek is in de rechtszaal. Ga bovendien na of de rechtszitting die je wilt bijwonen openbaar toegankelijk is. Sommige zittingen, zoals die in het jeugdstrafrecht, vinden achter gesloten deuren plaats. Andere zijn beperkt toegankelijk, zoals vreemdelingenzaken waarbij gebruik wordt gemaakt van telehoren (de vreemdeling wordt dan vanaf een andere locatie via een videoverbinding gehoord).

Juridisch-inhoudelijke voorbereiding kan relevant zijn als het gaat om een observatie in het kader van een positiefrechtelijk vak. In dat geval is het raadzaam om je vooraf te verdiepen in de juridische aspecten van een bepaald leerstuk. Ook kan het soms zinvol zijn je te verdiepen in de procesregels van een bepaald rechtsgebied omdat het dan beter te begrijpen is waarom bepaalde zaken tijdens de zitting gaan zoals ze gaan.

Om je observaties beter te kunnen structureren en om te voorkomen dat je bij de uitvoering van je onderzoek bepaalde aspecten vergeet, is het raadzaam om een zogenoemd observatieschema op te stellen. In een observatieschema staan alle aspecten opgesomd waar je op wilt letten, zodat je gemakkelijk aantekeningen kunt maken of kunt turven. Doordat je systematisch alle punten afloopt, zie je minder snel dingen over het hoofd. Vooral tegenvoorbeelden zou je anders snel over het hoofd zien. Het is mooi als het observatieschema theoretisch gefundeerd is. Ben je bijvoorbeeld geïnteresseerd in de externe openbaarheid van het strafproces, dan kun je bij voorbaat proberen te bedenken welke criteria je daarbij aan de dag legt. ${ }^{\mathbf{2 4}}$

Het is raadzaam om het observatieschema eerst uit te testen, bij voorkeur samen met een medestudent. Dat laatste heeft het voordeel dat je de observaties onderling kunt vergelijken om te bezien of er sprake is van intersubjectiviteit (de situatie waarbij meerdere onderzoekers tot dezelfde waarnemingen komen). Een andere mogelijkheid om te oefenen is door met medestudenten naar een documentaire als De Politierechter of De Vreemdelingenrechter te kijken. ${ }^{25}$

Een voorgestructureerde werkwijze heeft echter ook evidente nadelen. Een te grote focus op het formulier kan ertoe leiden dat de onderzoeker interessante aspecten die vooraf niet voorzien waren, over het hoofd ziet. Daarom is het zaak om in het observatieschema ook voor onvoorziene observaties ruimte in te lassen. In het uiteindelijke verslag van de observatie is het bovendien van belang dat je behalve op de punten van je observatieschema, ook een chronologische weergave kunt geven van wat ter sprake kwam. Daarom kun je ter zitting beter eerst een chronologisch verslag maken en proberen zo veel mogelijk aantekeningen van het verloop en de inhoud van de zitting te maken. Het observatieschema kun je vervolgens (direct) na afloop gebruiken als checklist voor de vraag of alle relevante onderdelen aan bod zijn gekomen.

\section{De uitvoering van de observatie}

$\mathrm{Na}$ al dit denkwerk vooraf kom je goed beslagen ten ijs. Let op dat je observatie al begint als je de rechtbank inloopt of zelfs al daarvoor, als je bijvoorbeeld telefonisch contact hebt gehad. Dit is temeer van belang voor observaties over aspecten als 'toegankelijkheid', 'begrijpelijkheid', 'openbaarheid'. Ook observaties over wat zich in de wachtruimten voordoet of in de tijd tussen de 
behandeling van twee zaken door, kunnen heel veelzeggend zijn. Het volgende fragment uit een onderzoek naar de communicatie tussen de rechter en de verdachte biedt daar een mooi voorbeeld van:

\begin{abstract}
'Als de zitting is afgelopen blijf ik op de tribune zitten in afwachting van de volgende zaak. Zodra de verdachte de zaal heeft verlaten ontspant de rechter zich wat meer, gaat ze wat meer ontspannen zitten en maakt een praatje met de mensen in de zaal. Zodra de volgende verdachte de zaal binnenloopt, schiet ze weer in haar rol. Ze gaat rechtop zitten en observeert de verdachte goed vanaf het moment dat hij binnenkomt. ${ }^{26}$
\end{abstract}

Lastig is dat je geen inzage hebt in het dossier, terwijl de procesdeelnemers daar doorgaans vaak naar verwijzen. In strafzaken vereist het onmiddellijkheidsbeginsel dat de rechter recht spreekt op basis van materiaal dat ter zitting naar voren is gebracht. ${ }^{27}$ Schriftelijke stukken moeten daarom op de zitting worden voorgelezen of samengevat. ${ }^{\mathbf{2 8}}$

Niet alle rechters zullen dat echter even uitgebreid doen. In gevallen waarin de verdachte verstek laat gaan en jij als enige toehoorder aanwezig bent, zullen rechters het overigens op prijs stellen als je je verexcuseert en de zaal verlaat. Anders zijn zij immers genoodzaakt de zaak louter en alleen voor jou mondeling te behandelen (als je geïnteresseerd bent in de vraag in hoeverre rechters aan dit beginsel tegemoetkomen, moet je natuurlijk juist blijven zitten, maar dat zal waarschijnlijk een ongemakkelijk gevoel opleveren).

Hierboven is al gewezen op het belang van het maken van (veel) notities. Probeer ter zitting niet al te opzichtig aantekeningen te maken; dat geeft mensen doorgaans een ongemakkelijk gevoel. Neem dus een klein notitieblokje mee en maak onopvallend aantekeningen. Vermijd om dezelfde reden het gebruik van laptop of iPad. Probeer ook te voorkomen dat je alleen op bepaalde momenten aantekeningen maakt, bijvoorbeeld als de rechter een onhandige opmerking maakt of als de rechter de advocaat terechtwijst. Let er ter zitting op of er omstandigheden zijn die de waarneming bemoeilijken, bijvoorbeeld lawaai of niet-functionerende microfoons en zorg ervoor dat je een goede plek uitzoekt in de zaal waarbij je zo min mogelijk last hebt van dergelijke belemmeringen.

\title{
7 De verslaglegging
}

Aantekeningen van de zitting kun je het beste meteen uitwerken, als alle gebeurtenissen nog vers in je geheugen zitten. Probeer je daarbij zo veel mogelijk te beperken tot uiterlijk waarneembaar gedrag, zonder daaraan meteen interpretaties of conclusies te verbinden. Dit is een van de moeilijkste aspecten van observatieonderzoek, omdat het interpreteren van waarnemingen en het indelen van mensen of gedrag in bepaalde categorieën nu eenmaal in ons gebakken zit. Een observatieopdracht is wat dat betreft een oefening in het negeren van voorkennis en vooroordelen.

Naast deze 'droge' beschrijving van wat je hebt waargenomen, is het raadzaam om aparte notities te maken van wat de observatie met jou als persoon deed: Welke aspecten vond je opvallend? Waren er aspecten die bepaalde emoties bij je opriepen (ontroering, verontwaardiging, medelijden, enz.)? Welke aspecten had je verwacht of juist niet? Binnen de sociale wetenschappen spreekt men van veldnotities. Deze notities dienen als basis voor de analyse van de observatie. 
In je observatieverslag dien je tot een synthese te komen van beschrijving en analyse. Het is mooi als het verslag behalve een nauwkeurige beschrijving van de situatie, ook inzicht geeft in de gedachtewereld van de onderzoeker (voor zover relevant). Bijvoorbeeld:

\begin{abstract}
'Op 11 oktober 2011 omstreeks 15:00 uur heb ik bij de meervoudige strafkamer van de rechtbank Alkmaar een rechtszitting bijgewoond van een strafzaak. Het slachtoffer was er niet, maar werd als toegevoegde partij wel vertegenwoordigd door een advocaat. Ik zat niet ver van het podium vandaan en kon alles goed volgen. De verdachte schonk geen aandacht aan mij en leek totaal geabsorbeerd door het schouwspel voor hem, met de Officier van Justitie (OvJ) aan de zijkant en de rechters voor hem. Het was meteen opvallend dat verdachtes raadsman geen plaats mocht nemen aan dezelfde tafel en redelijk ver van hem vandaan moest zitten. Dit versterkt de positie van verdachte als ongelijkwaardige partij en vooral als object van onderzoek, en de afzondering van zijn raadsman zal ongetwijfeld een gevoel van isolatie oproepen en het idee om er alleen voor te staan. Ik nam mij voor om er extra op te letten of deze afscheiding de communicatie met raadsman belemmerde.'
\end{abstract}

Terug naar het beschrijvende gedeelte. Probeer je daarin zoals gezegd zo veel mogelijk te beperken tot uiterlijk waarneembaar gedrag en probeer dat zo objectief mogelijk te doen. Hoe moeilijk dat is, blijkt wel uit het volgende voorbeeld. Een studente meldt in haar observatieverslag:

'De rechtzoekende (...) krijgt de vraag voorgelegd waar het hem in de kern om gaat. Uit zijn antwoord volgt geen eenduidig antwoord. Wel blijkt dat meneer erg boos is en ook behoorlijk "oververhit". De rechtzoekende vindt het moeilijk om te formuleren waar het hem in de kern om gaat. Het lijkt er op dat dit samenhangt met de boosheid van meneer.'

In haar toelichting voor medestudenten geeft deze studente aan het lastig te vinden in hoeverre je in je observatieverslag gewag kunt maken van emoties, omdat de waarneming van emoties zo subjectief is. Tegelijkertijd is het zeer relevant voor haar onderzoek dat onder meer gaat over de begrijpelijkheid van rechtszittingen voor de rechtzoekende.

Waaruit blijkt dat 'meneer erg boos is' en ook nog 'oververhit'? De relevantie van de boosheid is duidelijk: als mensen erg boos zijn, zijn ze minder goed in staat om informatie in zich op te nemen. De toevoeging 'oververhit' is echter erg subjectief en niet functioneel voor het verslag. Ook de boosheid zal nader omschreven moeten worden om het voor de lezer van het observatieverslag aannemelijk te maken. In de definitieve versie van haar observatieverslag doet deze studente dat ook door eraan toe te voegen:

'Zo verhief de rechtzoekende regelmatig zijn stem, bewoog hij onrustig op zijn stoel en stond hij soms op.'

Interpretatief onderzoek vergt wat wel genoemd wordt thick description ${ }^{\mathbf{2 9}}$ : een zeer nauwkeurige omschrijving waarbij het geobserveerde gedrag rijkelijk geilllustreerd wordt met voorbeelden. Je moet je daarbij onder meer afvragen of het geobserveerde gedrag voor ieder ander redelijk denkend mens zou leiden tot dezelfde conclusie (de rechtzoekende is boos). Probeer daarbij normatieve oordelen (of iets goed of slecht gaat) zo veel mogelijk te vermijden. Uiteraard 
kun je daar wel iets over zeggen, maar probeer dat onder een apart kopje (bijvoorbeeld analyse) te doen en dat ook goed te beargumenteren. Datzelfde geldt voor waarderingen als groot/klein (geef aantallen), veel/weinig (hoeveel precies?), lang/kort (hoeveel minuten) en typeringen als 'aardig', 'meelevend', 'verdrietig', enzovoort. Door te preciseren voorkom je dat de beschrijving van de zaak te zeer vermengd raakt met de eigen opvattingen van de onderzoeker. Een mooi voorbeeld biedt het verslag van een student die onderzoek deed naar het gebruik van juridisch jargon:
'De rechter maakt slechts beperkt gebruik van juridisch jargon. Ik heb de volgende woorden genoteerd: "tenlastelegging", "noodweer", "strafmaat", "hechtenis" en "niet-ontvankelijk". Het is opvallend dat de officier van justitie zich veel meer bedient van juridisch jargon. Zo gebruikt zij woorden als "requisitoir" en "strafoplegging". Daarnaast is ook haar taalgebruik veel formeler. Dit is ongetwijfeld het gevolg van het feit dat zij uit de tenlastelegging voorleest. Wat betreft het gebruik van "moeilijke woorden" maakt de rechter gebruik van het woord "escaleren" daarnaast gebruikt hij ook woorden als "woordenwisseling", "ontvelling" en "immateriële schade".'

Een ander voorbeeld van een thick description, tot slot, biedt deze student, die tijdens haar observaties vooral lette op de wijze van vraagstelling door de rechter:
'Wanneer rechter 3 Pagie ondervraagt, herhaalt ze voortdurend wat Pagie zegt. "Dat zou best kunnen", zegt hij bijvoorbeeld. "'Dat zou best kunnen', zegt u," zegt rechter 3 dan. Of, wanneer Pagie zegt: "Ik pin zo vaak," antwoordt rechter 3: "Ik pin zo vaak...?" Ook vraagt ze hem af toe iets, maar vult het dan zelf in. "Zegt u dat... nee, dat zegt u natuurlijk niet," zegt ze bijvoorbeeld. En: "U was er niet, hè?" Wanneer Pagies advocaat (of een van de andere advocaten) iets opmerkt doet ze dit nauwelijks; één keer zegt ze vragend: "Een beetje...?" nadat Pagies advocaat verklaart: "Dit waren een beetje mijn vragen." Meestal knikt rechter 3 instemmend en maakt goedkeurende geluiden ("Hm-hm"). Wel zegt ze, als de advocaat wil antwoorden nadat ze iets aan Pagie gevraagd heeft: "Het lijkt misschien dat ik naar u kijk, maar ik wil het toch echt vragen aan meneer Pagie."'

Dit voorbeeld brengt ons ook op een geheel ander punt, namelijk dat het in de regel beter is om geobserveerden niet met naam en toenaam in het verslag te noemen. Als het om een publieke figuur gaat, kan eventueel hiervan worden afgeweken omdat het anders wel erg gekunsteld wordt (bijvoorbeeld de zaakWilders), maar in andere gevallen is het beter om de personen (inclusief de geobserveerde rechters en andere professionals) ofwel anoniem te laten ofwel aan te duiden met een fictieve naam. In de hierboven aangehaalde gedragscode voor onderzoekers kwam dit punt al aan de orde, waar gesteld werd dat de privacy van betrokkenen afdoende beschermd dient te worden (zie paragraaf 4). Ook de Wet bescherming persoonsgegevens kan van toepassing zijn.

Terug naar de verslaglegging: het is mooi als een observatieverslag naast de vraagstelling, een beschrijvend gedeelte en een analyse in het licht van de vraagstelling, ook inzicht geeft in je werkwijze en de keuzes die je hebt gemaakt. Je kunt daarbij gebruikmaken van de terminologie die in dit artikel is aangereikt. Beargumenteer bijvoorbeeld (kort) of je rol verborgen of open was, waarom je wel of niet hebt gekozen voor een gestructureerde werkwijze door 
gebruikmaking van een observatieschema, enzovoort. Geef bovendien inzicht in de beperkingen van je gekozen werkwijze.

Tot slot is het zaak om in de conclusie nog eens kort terug te grijpen op de vraagstelling en op de literatuur die daaraan ten grondslag lag: wat heeft de observatie aan relevantie informatie opgeleverd? Vermijd generaliserende uitspraken, zoals 'de rechtspraak heeft zich ontwikkeld tot een professionele organisatie', op basis van één of slechts enkele observaties. Wel kun je in de conclusie aangeven wat een grootschaliger onderzoek met betrekking tot jouw vraagstelling zou kunnen opleveren en wat daar de maatschappelijke of wetenschappelijke relevantie van zou kunnen zijn.

\section{Tot slot}

In het voorgaande zijn enkele methodologische sleutelbegrippen toegelicht, zoals objectiviteit/subjectiviteit, selectiviteit van de waarneming, operationalisatie van de vraagstelling, interferentie en reactief gedrag bij respondenten. Besproken is hoe de objectiviteit van de waarneming bevorderd kan worden: door intersubjectieve waarneming, door te werken met een gerichte vraagstelling en (beperkt) voorgestructureerde observatieschema's en door te zoeken naar tegenvoorbeelden. Ook de objectiviteit van de verslaglegging is aan de orde gekomen, door te wijzen op het belang van thick description. Tot slot is op ethische aspecten gewezen, namelijk waar de afweging tussen openbaarheid van rechtspraak en privacy van de betrokken en anonieme verslaglegging ter sprake kwam. De bedoeling is dat studentonderzoekers met behulp van deze methodologische gereedschapskist tot meer diepgaande en creatieve observaties komen en hun keuzes beter kunnen expliciteren en verantwoorden in het verslag. Een bezoek aan de rechtbank levert informatie op die je verbeelding te boven gaat en is alleen daarom al de moeite waard. Als oefening in het observeren is het tevens een oefening in het onderdrukken van (voor)oordelen; vooral dit laatste aspect maakt de observatieopdracht ook nog bijzonder leerzaam.

\section{Literatuur}

\section{Bal 1988}

P. Bal, Dwangkommunikatie in de rechtszaal. Een onderzoek naar de verbale interaktie tussen rechter en verdachte tijdens de strafzitting van de politierechter (diss.), Arnhem: Gouda Quint 1988.

\section{Van Bennekom 2010}

W. van Bennekom, Op drijfijs. Over het functioneren van de rechtstaat, Amsterdam: Cossee 2010.

\section{Beyens \& Vanhamme 2008}

K. Beyens \& F. Vanhamme, 'Onderzoek naar rechtspreken als sociale praktijk', Tijdschrift voor Criminologie 50-4 (2008), p. 350-360.

\section{Bosch 2012}

R. Bosch, Wetenschapsfilosofie voor kwalitatief onderzoek, Den Haag: Boom/Lemma 2012.

\section{Bruinsma 2008}

F. Bruinsma, 'Wetenschap of woordkunst. Het werkgroeponderwijs als toets', 
$N J B, 83$, p. 2451-2455.

\section{Bruinsma 1995}

F. Bruinsma, Korte Gedingen. Een rechtssociologisch verslag, Zwolle: Tjeenk Willink 1995.

\section{Bryman 2008}

A. Bryman, Social Research Methods, Oxford: Oxford University Press 2008.

\section{Van de Bunt 1985}

H.G. van de Bunt, Officieren van Justitie. Verslag van een participerend observatieonderzoek (diss. Utrecht), Zwolle: Tjeenk Willink 1985.

\section{Callaghan 2005}

E. Callaghan, 'What They Learn in Court. Student Observations of Legal Proceedings', Teaching Sociology 2005, p. 213-220.

\section{Doornbos 2006}

$\mathrm{N}$. Doornbos, Op verhaal komen. Institutionele communicatie in de asielprocedure, Nijmegen: Wolff Legal Publishers 2006.

\section{Elchardus 2007}

M. Elchardus, Sociologie, een inleiding, Amsterdam: Pearson Educatie 2007.

\section{Van Duyne \& Verwoerd 1985}

P.C. Duyne \& J.R.A. Verwoerd, Gelet op de persoon van de rechter. Een observatie-onderzoek naar het strafrechtelijk beslissen in de raadkamer. WODC/Ministerie van Justitie 58, Den Haag: Staatsuitgeverij 1985.

\section{Geertz 1973}

C. Geertz, 'Thick Description. Toward an Interpretive Theory of Culture', in: C. Geertz, The Interpretation of Cultures. Selected Essays. New York: Basic Books 1973, p. 3-30.

\section{Goffman 1959}

E. Goffman, The Presentation of Self in Everyday Life, Garden City, NY:

Doubleday 1959.

\section{Griffiths 1995}

J. Griffiths, 'De jury als spiegel voor Nederland', NJB 1995, p. 1359.

\section{Hoefnagels 1970}

G.P. Hoefnagels, Rituelen ter terechtzitting. Een voorstudie van emoties, attituden en interacties tijdens het strafproces ter terechtzitting om te komen tot een methode van strafprocesvoering (oratie Rotterdam), Deventer: Kluwer 1970.

\section{Hol 2012}

A.M. Hol, Rechtspraak als theater; oftewel leren oordelen. Liber amicorum René Foqué, Den Haag: Boom Juridische uitgevers 2012, p. 71-84.

Holvast 


\section{Ippel \& Heeger-Hertter 2006}

P. Ippel, \& S. Heeger-Hertter, Sprekend de rechtbank. Alledaagse

communicatie in de Utrechtse zittingszaal, Nijmegen: Wolf Legal Publishers 2006.

\section{Kannegieter 1994}

G. Kannegieter, Ongelijkheid in de straftoemeting. De invloed van de sociale positie van de verdachte op strafrechtelijke beslissingen (diss. Groningen),

Groningen: Wolters-Noordhoff 1994.

\section{Kannegieter \& Strikwerda 1987}

G. Kannegieter, \& J. Strikwerda, Werkenden en werklozen voor de rechter. Een dossier- en observatie-onderzoek naar straftoemeting door de politierechter, Groningen: Criminologisch Instituut 1987.

\section{Köhne-Hoegen 2008}

E. Köhne-Hoegen, 'De raio-opleiding als socialisatieproces. Uittreders aan het woord', Recht der Werkelijkheid 2008-1, p. 11-34.

\section{Köhne-Hoegen 2006}

E. Köhne-Hoegen, 'Over de socialisatie en (her)opvoeding van de raio', Trema2006- 5, p. 186-190.

\section{Komter 1998}

M.L. Komter, Dilemmas in the Courtroom. A Study of Trials of Violent Crime in the Netherlands, Mahwah, NJ: Erlbaum 1998.

\section{Komter 1991a}

M.L. Komter, 'Discriminatie en interactie. Macht, culturele verschillen en spreekstijl als mogelijke bronnen van discriminatie in de rechtszaal', Tijdschrift voor Criminologie 33-3 (1991), p. 295-308.

\section{Komter $1991 b$}

M.L. Komter, 'De verdeling van kennis in de rechtszaal', Recht der Werkelijkheid 1991-2, p. 3-20.

\section{Latour 2009}

B. Latour, The Making of Law. An Ethnography of the Conseil d'Etat, Cambridge: Polity 2009.

\section{Malsch \& Nijboer 2005}

M. Malsch \& J.F. Nijboer, De zichtbaarheid van het recht. Openbaarheid van de strafrechtspleging, Deventer: Kluwer 2005.

\section{Manusov \& Patterson 2006}

V. Manusov \& M.F. Patterson (red.), The Sage Handbook of Nonverbal Communication, Thousand Oaks, CA: Sage 2006.

\section{O'Gorman \& Vander Laenen 2010}

A. O'Gorman \& F. vander Laenen, 'Ethische aspecten van het kwalitatief onderzoek', in: T. Decorte \& D. Zaitch (red.), Kwalitatieve methoden en technieken in de criminologie, Leuven/Den Haag: Acco 2010, p. 532-557. 


\section{Otte 2010}

R. Otte, De nieuwe kleren van de rechter, Den Haag: Boom Juridische uitgevers 2010.

\section{Van Rossum 1998}

W. van Rossum, Verschijnen voor de rechter. Hoe het hoort en het ritueel van Turkse verdachten in de rechtszaal, Amsterdam: Duizend \& Een 1998.

\section{Van de Sande 2003}

J.P. van de Sande, Gedragsobservatie, Groningen: Wolters-Noordhoff 2003.

\section{Silverman 1985}

D. Silverman, Qualitative Methodology \& Sociology, Aldershot: Gover 1985.

\section{Snel 1977}

B. Snel, Kijken in de rechtszaal. Een observatieonderzoek naar buitenjuridische factoren die ter zitting het vonnis van de politierechter beïnvloeden, Alphen aan den Rijn: Samsom 1977.

\section{Verhoeven 2011}

N. Verhoeven, Wat is onderzoek? Praktijkboek methoden en technieken voor het hoger onderwijs, Den Haag: Boom Lemma uitgevers 2011.

\section{Wermink, De Keyser \& Schuyt 2012}

H. Wermink, J. de Keyser \& P. Schuyt, 'Verschillen in straftoemeting in soortgelijke zaken', NJB 2012, p. 726-733.

\section{Zaitch 2010}

D. Zaitch, 'Participerende observatie in de criminologie', in: T. Decorte \& D. Zaitch (red.), Kwalitatieve methoden en technieken in de criminologie, Leuven/Den Haag: Acco 2010, p. 261-314.

\section{Over de auteur}

Nienke Doornbos is universitair docent aan de Faculteit Rechtsgeleerdheid van de Universiteit van Amsterdam. Zij doceert de minor Rechtswetenschappelijk onderzoek en het vak Recht en menselijk gedrag. In 2006 promoveerde zij op een observatieonderzoek naar de wijze waarop de Immigratie- en Naturalisatiedienst asielzoekers hoort in het kader van de asielprocedure. Zij publiceerde verder onder andere over ethische aspecten van empirisch onderzoek en over ontwikkelingen binnen (juridische) professies, zoals advocaten, rechters en tolken.

\section{Noten}

1 Enkele Nederlandse publicaties op dit vlak zijn van de hand van Hoefnagels 1970; Snel 1977; Van Duyne \& Verwoerd 1985; Van de Bunt 1985; Bal 1988; Komter 1991a, 1991b, 1998; Kannegieter 1994; Bruinsma 1995; Van Rossum 1998; Malsch \& Nijboer 2005; Ippel \& Heeger-Hertter 2006; Wermink, De Keyser \& Schuyt 2012. Zelf verrichte ik observatieonderzoek in aanmeld- en opvangcentra voor asielzoekers (Doornbos 2006).

2 Het meest bruikbaar is m.i. Zaitch 2010. Zie ook Callaghan 2005. 
3 Bijvoorbeeld Van de Sande 2003; Zaitch 2010; Bryman 2008, p. 400-434; Beyens \& Vanhamme 2008.

4 Elchardus 2007, p. 116. Zie voor socialisatie binnen de rechtenstudie Bruinsma 2008 en binnen de rechterlijke macht Köhne-Hoegen 2006 en 2008.

5 Zie bijvoorbeeld Malsch \& Nijboer 2005; Hol 2012.

6 Silverman (1985, hfst. 5) onderscheidt de antropologische etnografie, het interactionisme en de etnomethodologie, waaronder hij ook de conversatieanalyse rekent.

7 Zie bijvoorbeeld de publicaties van Komter (1991a, 1991b, 1996).

8 Bosch 2012, p. 12-22.

9 Malsch \& Nijboer 2005, p. 194.

10 Kannegieter \& Strikwerda 1987; Kannegieter 1994.

11 Wermink, De Keyser en Schuyt 2012.

12 Zie bijv. Manusov \& Patterson 2006. Een Nederlands observatieonderzoek naar non-verbale communicatie is van Van Rossum 1998.

13 De student verwijst hierbij naar de Oxford Latin Dictionary, Oxford University Press 1982.

14 Bal 1988, p. 93-100.

15 Dat blijkt bijv. uit de afkeer die Nederlanders hebben voor juryrechtspraak en het wantrouwen dat Amerikanen op hun beurt hebben voor rechtspraak die louter door professionele rechters (juristen) wordt beoefend. Zie Griffiths 1995 .

16 Vanwege het geheim van de raadkamer hebben in het verleden maar weinig onderzoekers daar toegang toe gekregen, zie wel: Van Duyne \& Verwoerd 1985.

17 Bryman 2008, p. 412.

18 Dit overkwam Rinus Otte (2010) na de publicatie van zijn boek De nieuwe kleren van de rechter. Door critici werd hij neergezet als een verrader, de 'wikileak' van de rechtspraak.

19 Zie bijvoorbeeld Van Bennekom (2010).

20 Zie Holvast (te verschijnen); Ippel \& Heeger-Hertter 2006.

21 O'Gorman \& Vander Laenen (2010, p. 536) gaan een stap verder en gaan er onder verwijzing naar de European and Social Research Council vanuit dat onderzoekers en onderzoekssubjecten volledig moeten worden geïnformeerd over het doel, de methoden en de wijze waarop het onderzoek zal worden benut.

22 Zie o.m. zijn etnografisch onderzoek naar de Franse Raad van State, Latour 
2009.

23 www.rechtspraak.nl/RECHT-IN-NEDERLAND/IN-DE-

RECHTSZAAL/KIJKJEINDERECHTSZAAL/Pages/default.aspx.

24 Malsch \& Nijboer 2005, hfdst. 2.

25 www.hollanddoc.nl/kijk-luister/documentaire/d/devreemdelingenrechter.html.

26 Een promovendus in de rechtssociologie zou dit verschijnsel mooi kunnen duiden aan de hand van de theatermetafoor in termen van 'impression management' en het onderscheid 'frontstage' en 'backstage' (Goffman 1959).

27 Art. 348 en 350 Wetboek van Strafvordering.

28 Art. 297 Wetboek van Strafvordering.

29 Geertz 1973.

(c) Boom Juridische uitgevers 